\title{
Efektivitas Rebusan Daun Sirih Merah (Piper Crocatum) Terhadap Penurunan Kadar Gula Darah Penderita Diabetes Mellitus
}

\author{
Sri Mindayani ${ }^{\mathrm{a}^{*}}$, Wardhah Susanti ${ }^{\mathrm{b}}$, Neli Agustin ${ }^{\mathrm{c}}$, Jawar Tina ${ }^{\mathrm{d}}$ \\ Universitas Baiturrahmah, Jalan Raya By Pass Km 15, Padang, 25158, Indonesia \\ asrimindayani@fkm.unbrah.ac.id, ${ }^{\mathrm{b}}$ wardhahsusanti@gmail.com, ${ }^{\mathrm{c}}$ nelliagustin99@gmail.com, djawartina0203@gmail.com \\ * corresponding author
}

ARTICLE INFO

Keywords

Diabetes mellitus

Red betel leaf

\begin{abstract}
Diabetes mellitus is a metabolic disease that arises in a person due to an increase in blood glucose levels above normal values. WHO Data (2016) showed the case of diabetes in Indonesia has an increased tendency of $5.7 \%$ in 2007 to $6.9 \%$ in 2016 . This Data also showed that diabetes with complications is the third highest cause of death in Indonesia. Referring to national prevalency, the Province of West Sumatra has total Diabetes Mellitus as much as $1.3 \%$ which is in the order of 14 of the 33 provinces in Indonesia. Incidence of diabetes mellitus disease in Padang City is in the sixth order with the amount of 22,523 cases (DKK Padang, 2017). This research aims to determine the effectiveness of the decoction of red betel leaf to decrease blood sugar levels of people with diabetes mellitus. The research design used was Quasy Experimentwith pretests and posttest group. This research conducted in the area of Puskesmas Padang Pasir from April to August 2019. Sampling techniques was purposive sampling with 10 research subjects, 5 people with $100 \mathrm{ml}$ decoction of betel leaf and 5 people are given a $125 \mathrm{ml}$ decoction of betel leaf for three times daily. The results of the average value before and after the intervention of blood sugar levels can be seen a decrease in blood sugar levels of respondents at a dose of $125 \mathrm{ml}$. In addition, the time of intervention should be more than 7 days for the effectiveness.
\end{abstract}

\section{Pendahuluan}

Diabetes mellitus adalah penyakit metabolisme yang timbul pada seseorang karena adanya peningkatan kadar glukosa darah di atas nilai normal [1]. Indonesia menempati peringkat ketujuh untuk prevalensi penderita diabetes tertinggi di dunia dengan jumlah estimasi orang dengan diabetes sebesar 10 juta jiwa [2]. Data menunjukkan kasus diabetes di Indonesia memiliki kecenderungan meningkat yaitu dari 5,7\% di tahun 2007 menjadi 6,9\% di tahun 2016[3]. Data ini juga menunjukkan bahwa diabetes dengan komplikasi merupakan penyebab kematian tertinggi ketiga di Indonesia. Merujuk kepada prevelensi nasional, Provinsi Sumatera Barat memiliki total Diabetes Mellitus sebanyak 1,3\% yang berada di urutan ke 14 dari 33 provinsi yang ada di Indonesia. Berdasarkan umur, penderita banyak dalam rentang usia 56-64 tahun dengan prevelensi sebesar 4,8\% [1]. Kejadian penyakit diabetes mellitus di Kota Padang berada pada urutan keenam dengan jumlah 22.523 kasus [4].

Diabetes mellitus dapat diklasifikasikan menjadi empat kelompok, yaitu diabetes mellitus tipe I, tipe II, diabetes mellitus karena kehamilan, dan diabetes mellitus tipe sekunder akibat 
kerusakan pankreas. Diabetes mellitus tipe-1 merupakan penyakit diabetes mellitus yang tergantung pada insulin dari luar tubuh untuk menurunkan kadar glukosa darah karena sel- $\beta$ pancreas penderita tidak mampu memproduksi insulin dalam jumlah mencukupi akibat proses autoimun tubuh atau serangan virus. Diabetes mellitus tipe-2 merupakan penyakit diabetes yang paling banyak terjadi (90-95\% kasus). Diabetes mellitus tipe-2 sangat berhubungan dengan keadaan resistensi yang biasanya disebabkan oleh obesitas [5]. Stres oksidatif yang terjadi dapat menimbulkan radikal bebas di dalam tubuh, dan akan mengganggu kerja insulin sehingga insulin tidak maksimal dalam menurunkan kadar glukosa darah. Selain itu, keadaan hiperglikemia akan dapat memproduksi banyak radikal bebas [6], dan kondisi hiperglikemia kronis pada diabetes dapat menyebabkan terjadinya autooksidasi glukosa [7]. Senyawa radikal bebas yang terbentuk dalam jumlah besar akan meningkatkan stres oksidatif dan semakin banyak merusak senyawa-senyawa makromolekul lainnya seperti lipida dan protein. Kerusakan makromolekul tersebut akan menyebabkan penurunan fungsi kerja organ sehingga menimbulkan penyakit lainnya, seperti kebutaan, gagal ginjal, dan aterosklerosis [8].

Sirih merah saat ini tidak hanya digunakan untuk tanaman hias dan kelengkapan upacara adat saja [9]. Selain memiliki daya tarik khas, daun sirih merah juga bermanfaat sebagai tanaman obat berbagai jenis penyakit terutama diabetes mellitus. Hasil penelitian [10], sirih merah mengandung flavonoid, alkaloid, saponin, senyawa polifenolat, tannin dan minyak atsiri. Secara empiris sirih merah dapat menyembuhkan berbagai jenis penyakit seperti diabetes mellitus, hepatitis, batu ginjal, menurunkan kolesterol, mencegah stroke, asam urat, hipertensi, radang liver, radang prostat, radang mata, keputihan, maag, kelelahan, nyeri sendi dan memperhalus kulit. Daun sirih merah lebih banyak mengandung senyawa-senyawa kimia yang penting untuk berbagai macam penyakit daripada jenis daun sirih lainnya seperti daun sirih hijau dan daun sirih hitam [11].

Selama penanggulangan diabetes, obat hanya merupakan pelengkap dari diet. Obat diabetes oral mungkin berguna untuk penderita yang alergi terhadap insulin atau yang tidak menggunakan suntikan insulin. Sementara penggunaannya harus dipahami, agar ada kesesuaian dosis dengan indikasinya, tanpa menimbulkan hipoglikemia [12]. Obat anti diabetes oral kebanyakan memberikan efek samping yang tidak diinginkan, maka para ahli mengembangkan sistem pengobatan tradisional untuk diabetes mellitus yang relatif aman dan mudah dalam pembuatannya [12]. Selain itu, untuk mencari pengobatan saat ini sangat memerlukan biaya dan sebagai alternatif banyak anggota masyarakat untuk kembali ke pengobatan tradisional yang dapat dipercaya. Potensi sirih merah sebagai tanaman obat multi fungsi sangat besar, sehingga perlu ditingkatkan dalam penggunaannya sebagai bahan obat modern [9].

Hasil penelitian menunjukkan bahwa ekstrak daun sirih merah dapat menurunkan kadar gula darah secara signifikan(13). Hasil penelitin ini sejalan dengan penelitian [14] yang mengatakan bahwa rebusan daun sirih merah mampu menurunkan kadar gula darah penderita Diabetes Mellitus pada lansia. Pemberian rebusan daun sirih merah dapat menurunkan kadar gula darah tikus putih yang diinduksi alloxan [15]. Dari uraian di atas, peneliti berinisiatif melakukan penelitian terhadap efektivitas rebusan air daun sirih dalam penurunan kadar gula darah.

\section{Metode}

Desain penelitian yang digunakan adalah Quasy Experiment denganpenelitian menggunakan pretest dan postest. Penelitian ini dilakukan dalam wilayah kerja Puskesmas Padang Pasir. Pelaksanaan penelitian dilakukan dari bulan April sampai Agustus 2019.Teknik pengambilan sampel dilakukan secara purposive sampling sebanyak 10 subjek penelitian, dimana 5 orang dengan perlakuan pemberian 100 mili liter rebusan daun sirih dan 5 orang lagi diberi perlakuan 125 mili liter rebusan daun sirih untuk tiga kali sehari. Alat terdiri dari Glucometer/easy touch GCU (Glucose, Cholesterol, Uric Acid), gelas beaker/ukur, gelas minum, panci, kompor, dan timbangan. Bahan yang dibutuhkan daun sirih merah dan air mendidih.

Cara kerja dalam penelitian ini ada tiga, peramuan rebusan air daun sirih merah, tahapan penelitian dan pemberian ramuan rebusan sirih merah.Pembuatan rebusan daun sirih merah 
sebanyak 3 lembar diambil yang cukup tua dan tidak terlalu muda dicuci bersih, kemudian dipotong kecil-kecil diatas talenan. Direbus bersama 600 mili liter air hingga volumenya menjadi 150 mili liter. air rebusan daun sirih merah diminum 3 kali/hari masing-masing 50 mili liter menurut [11]. Berdasarkan perhitungan diatas, peneliti menggunakan 2 dosis yang berbeda, yaitu 100 mili liter dan 125 mili liter untuk tiga kali sehari. Dalam tahapan penelitian, peneliti menemui keluarga dan penderita diabetes mellitus di rumahnya. Penderita diabetes mellitus (subjek penelitian) dilakukan orientasi terhadap tujuan penelitian. Peneliti membuat kontrak dengan penderita diabetes melitus yang bersedia menjadi sampel. Setiap responden diberikan ramuan daun sirih merah sesuai dengan dosisi yang ditentukan yaitu lima responden untuk dosis 100 mili liter dan lima responden untuk dosis 125 mili liter lalu meminum rebusan air daun sirih merah tiga kali dalam sehari. Pertama meminum air rebusan daun sirih merah antara pukul 08.00-09.00 WIB, kedua sekitar pukul 13.00-14.00 WIB, ketiga sekitar pukul 19.00-20.00 WIB.Peneliti mencatat skala pengukuran kadar gula darah sebelum pemberian rebusan air daun sirih merah dan setelah pemberian ramuan daun sirih merah pada hari ketujuh dan dicatat pada lembar hasil penelitian.

Dalam melakukan penelitian ini, peneliti dibantu oleh 2 pengumpul data yang telah dilatih dalam melakukan pemberian rebusan air daun sirih merah dan tenaga medis sebanyak 1 orang dokter untuk melakukan pengukuran kadar gula darah. Data yang dikumpulkan berupa data primer dan data sekunder. Data yang diambil adalah hasil pengukuran kadar gula darah kelompok subjek sebelum dan sesudah pemberian perlakuan dengan terapi rebusan air daun sirih merah. Instrumen yang digunakan untuk mengukur kadar gula darah menggunakan glucometer atau easy touch GCU, stetoskop dan dicatat dalam lembaran hasil pengukuran yang telah disediakan. Sedangkan data karakteristik subjek penelitian dikumpulkan dengan wawancara berupa nama, umur, jenis kelamin, pendidikan, berat badan, tinggi badan, pekerjaan, pola makan dan aktivitas fisik.

Analisis dilakukan secara bertahap dimulai dengan analisis univariat, dilanjutkan dengan analisis bivariat. Analisis univariat bertujuan untuk mengetahui gambaran karakteristik subjek penelitian dan variabel penelitian. Analisis bivariat digunakan untuk mengetahui apakah ada keefektifitasan pemberian rebusan daun sirih merah dalam menurunkan kadar gula darah penderita diabetes mellitus uji statistik yang digunakan uji T Dependent.

\section{Hasil dan Diskusi}

\section{Karakteristik Responden}

1.1 Umur Responden

Karakteristik berdasarkan umur populasi dapat dilihat pada tabel berikut:

Tabel 1. Distribusi Frekuensi Umur Responden

\begin{tabular}{ccc}
\hline Umur (tahun) & $\mathbf{N}$ & $\mathbf{\%}$ \\
\hline $36-45$ & 1 & 10 \\
$46-55$ & 6 & 60 \\
$56-65$ & 3 & 30 \\
\hline Total & $\mathbf{1 0}$ & $\mathbf{1 0 0}$ \\
\hline
\end{tabular}

Dari tabel diatas diketahui sebagian besar populasi berumur 46-55 tahun (33,3\%). Menurut Departemen Kesehatan RI tahun 2013, penderita diabetes mellitus banyak dalam rentang umur 5664 tahun dengan prevelensi sebesar 4,8\%. Dari data diatas didapatkan bahwa penderita diabetes mellitus juga diderita oleh rentang umur dibawah 56 tahun. 


\subsection{Jenis Kelamin Responden}

Karakteristik berdasarkan jenis kelamin populasi dapat dilihat pada tabel berikut:

Tabel 2. Distribusi Frekuensi Jenis Kelamin Responden

\begin{tabular}{ccc}
\hline Jenis Kelamin & $\mathbf{N}$ & \% \\
\hline Laki-laki & 1 & 10 \\
Perempuan & 9 & 90 \\
\hline Total & $\mathbf{1 0}$ & $\mathbf{1 0 0}$
\end{tabular}

Dari tabel di atas diketahui sebagian pepolasi adalah perempuan (90\%).

\section{Analisis Univariat}

2.1 Gambaran Kadar Gula Darah Sebelum Intervensi (pre-test) pada Kelompok Eksperimen Dengan Dosis 100 mili liter

Gambaran rata-rata kadar gula darahresponden sebelum pemberian rebusan daun sirih merah pada kelompok eksperimen dengan dosis 100 mili liter dapat dilihat pada tabel berikut:

Tabel 3. Gambaran Kadar Gula Darah Responden Sebelum Intervensi Pada Kelompok Eksperimen Dosis 100 mili liter

\begin{tabular}{clccc}
\hline No & Nama Responden & Kadar Gula Darah & Mean & SD \\
\hline 1 & Fitriyani & $213 \mathrm{mg} / \mathrm{dl}$ & & \\
2 & Yulinar & $275 \mathrm{mg} / \mathrm{dl}$ & & \\
3 & Jali & $277 \mathrm{mg} / \mathrm{dl}$ & 277,00 & 40,243 \\
4 & Sunarti (Yet) & $300 \mathrm{mg} / \mathrm{dl}$ & & \\
5 & Melly Purnama & $320 \mathrm{mg} / \mathrm{dl}$ & & \\
\hline
\end{tabular}

Pada tabel menunjukan bahwa kadar gula rata-rata responden sebelum intervensi adalah 277 $\mathrm{mg} / \mathrm{dl}$ dengan standar deviasi 40,243.

\subsection{Gambaran Kadar Gula Darah Responden Setelah Intervensi (post-test) pada Kelompok Eksperimen Dengan Dosis 100 mili liter}

Gambaran rata-rata rata-rata kadar gula darahresponden setelah pemberian rebusan daun sirih merah pada kelompok eksperimen dengan dosis 100 mili liter dapat dilihat pada tabel berikut:

Tabel 4. Gambaran Kadar Gula Darah Responden Setelah Intervensi Pada Kelompok EksperimenDosis 100 mili liter

\begin{tabular}{clccc}
\hline No & Nama Responden & Kadar Gula Darah (mg/dl) & Mean & SD \\
\hline 1 & Fitriyani & 202 & & \\
2 & Yulinar & 245 & & \\
3 & Jali & 207 & 232,40 & 42,170 \\
4 & Sunarti (Yet) & 303 & & \\
5 & Melly Purnama & 210 & & \\
\hline
\end{tabular}

Pada tabel menunjukan bahwa kadar gula rata-rata responden sebelum intervensi adalah 232,40 $\mathrm{mg} / \mathrm{dl}$ dengan standar deviasi 42,170.

\subsection{Gambaran Kadar Gula Darah Sebelum Intervensi (pre-test) pada Kelompok Eksperimen \\ Dengan Dosis 125 mili liter}

Gambaran rata-rata kadar gula darah responden sebelum pemberian rebusan daun sirih merah pada kelompok eksperimen dengan dosis 125 mili liter dapat dilihat pada tabel berikut: 
Tabel 5. Gambaran Kadar Gula Darah Responden Sebelum Intervensi Pada Kelompok EksperimenDosis 125 mili liter

\begin{tabular}{clccc}
\hline No & Nama Responden & Kadar Gula Darah & Mean & SD \\
\hline 1 & Syafiyanti (Yen) & $252 \mathrm{mg} / \mathrm{dl}$ & & \\
2 & Erlita Liyanti & $401 \mathrm{mg} / \mathrm{dl}$ & & \\
3 & Nurmayanti (Lebok) & $344 \mathrm{mg} / \mathrm{dl}$ & 350,80 & 69,976 \\
4 & Yuliarni & $325 \mathrm{mg} / \mathrm{dl}$ & & \\
5 & Rusnita & $432 \mathrm{mg} / \mathrm{dl}$ & & \\
\hline
\end{tabular}

Pada tabel menunjukan bahwa kadar gula rata-rata responden sebelum intervensi adalah 350,80 $\mathrm{mg} / \mathrm{dl}$ dengan standar deviasi 69,976.

\subsection{Gambaran Kadar Gula Darah Responden Setelah Intervensi (post-test) pada Kelompok Eksperimen Dengan Dosis 125 mili liter}

Gambaran rata-rata rata-rata kadar gula darah responden setelah pemberian rebusan dun sirih merah pada kelompok eksperimen dengan dosis 125 mili liter dapat dilihat pada tabel berikut:

Tabel 6. Gambaran Kadar Gula Darah Responden Setelah Intervensi Pada Kelompok EksperimenDosis 125 mili liter

\begin{tabular}{clccc}
\hline No & Nama Responden & Kadar Gula Darah & Mean & SD \\
\hline 1 & Syafiyanti (Yen) & $368 \mathrm{mg} / \mathrm{dl}$ & & \\
2 & Erlita Liyanti & $506 \mathrm{mg} / \mathrm{dl}$ & & \\
3 & Nurmayanti (Lebok) & $382 \mathrm{mg} / \mathrm{dl}$ & 371,80 & \multirow{2}{*}{92,732} \\
4 & Yuliarni & $240 \mathrm{mg} / \mathrm{dl}$ & & \\
5 & Rusnita & $358 \mathrm{mg} / \mathrm{dl}$ & & \\
\hline
\end{tabular}

Pada tabel menunjukkan bahwa kadar gula rata-rata responden sebelum intervensi adalah $371,80 \mathrm{mg} / \mathrm{dl}$ dengan standar deviasi 92,732.

\section{Analisis Bivariat}

3.1 Hasil Uji Statistik Perbedaan Kadar Gula Darah Sebelum dan Setelah Pada Kelompok Eksperimen Dosis 100 mili liter

Tabel 7. Gambaran Rata-rata Kadar Gula Darah Responden Pada Kelompok Eksperimen Dosis 100 mili liter

\begin{tabular}{cc}
\hline Mean sebelum intervensi & Mean setelah intervensi \\
\hline 277,00 & 232,40 \\
\hline
\end{tabular}

Berdasarkan nilai rata-rata mean didapatkan mean sebelum intervensi sebesar 277,00 dan mean setelah intervensi sebesar 232,40. Terjadinnya penurunan kadar gula darah sebesar 44,60. Hal ini menunjukkan bahwa tidak terdapat perbedaan sebelum dan setelah intervensi. Penelitian ini tidak sejalan dengan hasil penelitian [16], yang menunjukkan bahwa ekstrak daun siruh merah dapat menurunkan kadar gula darah secara signifikan. Selain itu penelitian ini tidak sejalan juga dengan hasil penelitian [14] yang menunjukkan bahwa rebusan daun sirih merah mampu menurunkan kadar gula darah penderita diabates mellitus.

Penelitian ini sejalan dengan hasil penelitian [17], menunjukan bahwa pengaruh air rebusan duan sirih merah terhadap glukosa darah post prandial orang normal terlihat tidak konsisten. Dalam tiga kali perlakuan, pengaruh air rebusan terhadap glukosa darah tampak pada hari kedua, sedangkan hari pertama dan ketiga tidak tampak adanya pengaruh. 
Menurut asumsi peneliti, dari nilai rata-rata sebelum dan setelah intervensi dapat dilihat adanya penurunan kadar gula darah responden. empat orang mengalami penurunan kadar gula darah dan satu orang mengalami kenaikan kadar gula darah berdasarkan hasil pengamatan di lapangan selama intervensi.

3.2 Hasil Uji Statistik Perbedaan Kadar Gula Darah Sebelum dan Setelah Pada Kelompok Eksperimen Dosis 125 mili liter

Tabel 8. Gambaran Rata-rata Kadar Gula Darah Responden Pada Kelompok Eksperimen Dosis 125 mili liter

\begin{tabular}{cc}
\hline Mean sebelum intervensi & Mean setelah intervensi \\
\hline 350,80 & 371,80 \\
\hline
\end{tabular}

Berdasarkan nilai rata-rata mean didapatkan mean sebelum intervensi sebesar 350,80 dan mean setelah intervensi sebesar 371,80 . Hal ini menunjukkan bahwa tidak terdapat perbedaan sebelum dan setelah intervensi. Penelitian ini tidak sejalan dengan hasil penelitian [16] yang menunjukkan bahwa ekstrak daun siruh merah dapat menurunkan kadar gula darah secara signifikan. Selain itu penelitian ini tidak sejalan juga dengan hasil penelitian [14] yang menunjukkan bahwa rebusan daun sirih merah mampu menurunkan kadar gula darah penderita diabates mellitus.

Penelitian ini sejalan dengan hasil penelitian [17] menunjukan bahwa pengaruh air rebusan duan sirih merah terhadap glukosa darah post prandial orang normal terlihat tidak konsisten. Dalam 3 kali perlakuan, pengaruh air rebusan terhadap glukosa darah tampak pada hari kedua, sedangkan hari pertana dan ketiga tidak tampak adanya pengaruh.

Menurut asumsi peneliti, tidak adanya perbedaan sebelum dan setelah intervensi dikarenakan kontrol pola konsumsi yang tidak dilakukan oleh peneliti. Seperti pada ibu Syafiyanti, pada saat meminum rebusan daun sirih merah diiringi dengan memakan sesuatu sebagai penghilang rasa pahit dari sirih merah seperti roti, pisang, dan sebagainya.

\section{Kesimpulan}

Beberapa hal yang dapat disimpulkan dari hasil kegiatan pendampingan komunitas adalah sebagai berikut:

1. Pengetahuan siswa tentang bahaya narkoba, HIV-AIDS dan kesehatan reproduksi remaja dapat meningkat dengan dilakukannya penyuluhan kesehatan.

2. Pemahaman siswa tentang bahaya narkoba, HIV-AIDS dan kesehatan reproduksi remaja sampai dengan membuat pemecahan masalah dapat meningkat dengan dilakukannya pelatihan pendidikan sebaya.

3. Pengetahuan orang tua tentang bahaya narkoba, HIV-AIDS dan kesehatan reproduksi remaja dapat meningkat dengan dilakukannya penyuluhan kesehatan.

\section{Saran} berikut:

Beberapa saran yang dapat diuraikan dari pendampingan komunitas ini adalah sebagai

1. Perlu adanya kegiatan rutin dalam peningkatan pengetahuan siswa tentang bahaya narkoba, HIV-AIDS dan khususnya kesehatan reproduksi remaja yang diberikan pihak sekolah atau UKS.

2. Perlu adanya kegiatan selanjutnya untuk memberikan pelatihan (Training of Trainer) untuk dokter remaja sekolah.

3. Kegiatan selanjutnya perlu memberikan pelatihan pembuatan program Usaha Kesehatan Sekolah 


\section{Referensi}

[1] Sensus Penduduk Indonesia Tahun 2017

[2] Survei Demografi Kesehatan Indonesia Tahun 2017

[3] BKKBN. (2017). Pedoman Pengelolaan Pusat Informasi dan Konseling Remaja dan Mahasiswa (PIK Remaja/Mahasiswa). Jakarta

[4] Unicef. (2017). Unicef Indonesia : Laporan Tahunan 2012. Unicef Indonesia. Jakarta

[5] Kementerian Kesehatan RI. 2017. Perkembangan HIV/AIDS di Tahun 2013. PP\&PL Kementerian Kesehatan RI. Jakarta

[6] Aisyaroh, N. (2009). Kesehatan Reproduksi Remaja, Jurnal Majalah Ilmiah Sultan Agung Diterbitkan oleh Unissula

[7] Karakternews, (2017). http://karakternews.com/hukum-kriminal/hukum/polres-deli-serdangringkus-79-pengedar-narkoba. Diakses 25 April 2015 pukul 23.00

[8] Mappiare, A. (1990). Psikologi remaja. Surabaya : Percetakan Usaha Nasional.

[9] Survei Demografi Kesehatan Indonesia Tahun 2016

[10] Survei Kesehatan Rumah Tangga Indonesia Tahun 2017

[11] Gunawan R, Pratama M, Sulaiman, Anggriani, Gurning F. (2018). Increasing Of HIV/AIDS Prevention And Drugs Through Whatsapp Based Training And Assistance In Adolescents In Batang Kuis Deli Serdang District. International Journal of Scientific and Engineering research. Vol. 9 (9). 